\title{
Mengapa Kita Perlu Regulasi Penyiaran?
}

\author{
M. Rochim
}

ABSTRACT

\begin{abstract}
The rise of media market in Indonesia has obvious impacts in the world of Indonesian mediaespecially television. There are more than 11 national commercial televisions, and hundreds of local television today - thanks for SK Menteri Penerangan Th. 111/1990 which allowing mass media business to be operated in Indonesia. But, years after such liberalizations, televisions has growing rapidly without real regulations. Complaints come from citizens concerning the low quality of TV programs, the tendency of mono-culturalization, and unhealthy market (and content) due to monopolistic ownership. These complaints marked the needs of broadcasting regulation. Based on the assumption frequency as public's own, therefore, the use of frequencies must be dedicated to educate and serve public needs.
\end{abstract}

Kata kunci: penyiaran, regulasi, komisi penyiaran indonesia

\section{Pendahuluan}

Televisi adalah media yang paling luas dikonsumsi oleh masyarakat Indonesia. Jenis media ini tidak mensyaratkan pemirsanya dalam rangka menikmati tayangannya. Untuk masyarakat Indonesia yang lebih kuat budaya lisannya, media televisi tidak memiliki jarak yang jauh. Menonton televisi berbeda dengan budaya baca tulis. Perkembangan televisi bergerak jauh lebih cepat dibanding media cetak.

Ketika lahir pertama kali di Indonesia pada Agustus 1962 melalui TVRI, mungkin belum terbayangkan betapa televisi pada akhirnya bakal menjadi salah satu elemen yang sulit untuk dihindari, untuk tidak mengatakannya sebagai yang terpenting, dari rutinitas keseharian rakyat
Indonesia. Meskipun bisa dibilang tidak murah tetapi rata-rata hampir semua rumah tangga di Indonesia mempunyai pesawat televisi. Ini berbeda dengan media cetak yang dikonsumsi hanya oleh sebagian orang saja.

Televisi sudah menjadi "benda wajib" yang harus hadir di tengah ruang keluarga. Sebuah rumah baru dikatakan sempurna jika "benda" ini sudah hadir. Pendek kata, televisi telah menjadi bagian dari keseharian hidup orang Indonesia. Sejak dikeluarkannya SK Menteri Penerangan No 111 Tahun 1990, industri dan bisnis media televisi berubah menjadi marak. Awalnya adalah tahun 1987/1988, ketika RCTI diizinkan mengudara dengana menggunakan decoder, yang kemudian diikuti oleh SCTV(1989), TPI(1991), ANTeve(1993) 
dan, Indosiar (1994).

Kebebasan untuk berekspresi tidaklah diwariskan dari para pendiri bangsa kepada pengelola media cetak dan penyiaran secara terpisah. Ini adalah hak yang paling dasar bagi masyarakat. Para pembuat rumusan hak asasi manusia percaya bahwa pemerintah tidak akan melarang kebebasan individu untuk bicara dan menulis, bebas dari rasa takut dan sebagainya. Kebebasan untuk menyampaikan pendapat dan hak atas informasi ini kemudian dilembagakan dalam bentuk media cetak dan media penyiaran. Kedua lembaga tersebut bertugas untuk mencari, mengolah, dan menyampaikan informasi yang ada di sekitar masyarakat bagi masyarakat umum secara luas.

Dalam usahanya mencari, mengolah, dan menyampaikan informasi ini maka haruslah dibarengi dengan seperangkat aturan yang jelas yang pada gilirannya bisa secara baik mengatur hak dan kewajiban dari sebuah lembaga media baik cetak maupun penyiaran. Maka dibuatlah undangundang untuk mengaturnya.

Kita mengenal Undang-Undang no 40 tahun 1999, mengenai Pers, yang isinya secara umum mengatur tentang regulasi media cetak. Kitapun mengenal Undang-Undang No 32 Tahun 2002, mengenai Penyiaran. Pertanyaannya kemudian mengapa peraturan bagi media penyiaran jauh lebih'ketat' dibanding media cetak. Media cetak selama ini menikmati keuntungan dengan adanya sedikit proteksi dari pemerintah dibanding dengan media penyiaran. Ini dimungkinkan karena pemerintah dan masyarakat menilai media penyiaran mempunyai kemampuan lebih untuk mempengaruhi nilai-nilai sosial yang ada di masyarakat dibandingkan dengan media cetak.

Dalam sebuah pemilu, misalnya, media penyiaran jauh mempengaruhi khalayak daripada media cetak. Jika menilik kasus di Indonesia, maka kita bisa melihat pada jatuhnya para korban akibat tayangan acara Smackdown. Atau seperti yang diungkapkan Gerard J. Waldron, seorang media lawyer yang menjadi penasihat Kongres AS, yang dalam satu kesempatan diskusi di tahun 1998, bersama Menteri Penerangan (waktu itu), Yunus
Yosfiah dan para pemimpin media. Ia menjawab pertanyaan, mengapa di AS media cetak sepenuhnya bebas sedangkan media elektronik harus diregulasi? Waldron menjawab, "Karena siaran radio dan televisi bisa tiba-tiba masuk ke ruang keluarga Anda." Dengan demikian regulasi itu penting, paling tidak untuk melindungi kepentingan umum, seperti perlindungan anak dan norma keluarga. Karena sifat mempengaruhinya yang dirasa lebih kuat inilah maka regulasi untuk media penyiaran jauh lebih 'ketat' dibuat pemerintah jika dibandingkan dengan media cetak.

\section{Perumusan Masalah}

Menilik latar belakang tersebut di atas, maka muncul pertanyaan, "alasan apa yang membuat kita merasa perlu adanya regulasi bagi media penyiaran kita?"

\section{Pembahasan}

Ada tiga alasan utama mengapa pemerintah membuat peraturan langsung bagi industri telekomunikasi. Pertama, frekuensi udara atau spektrum frekuensi radio selaku ranah publik adalah komoditas yang terbatas. Spektrum frekuensi radio di udara yang menjadi medium penyiaran bukanlah milik pengusaha/perusahaan media penyiaran, melainkan milik publik seperti halnya kekayaan hayati di laut dan darat (baik hasil hutan maupun barang tambang yang terkandung dalam bumi). Kekayaan hayati ini milik publik dan tidak bersifat tak terbatas sehingga keberadaannya harus dilindungi oleh negara sebagai representasi publik. Ini berbeda halnya dengan media cetak yang tidak menggunakan ranah publik (mau cetak berapa pun tirasnya, media cetak tidak dibatasi). Karena keterbatasannya ini, adalah tidak mungkin semua orang memakai secara bersamaan untuk menyiarkan sesuatu kecuali justru hal yang mau disiarkannya itu tidak akan tersiarkan.

Sebagai contoh (untuk kasus Jakarta) kanal FM yang disediakan oleh Balai Monitoring adalah $400 \mathrm{Khz}$, yang berarti hanya ideal bagi 48 channel siaran radio. Tetapi kenyataannya, pada saat ini hampir 60 stasiun radio beroperasi di Jakarta. Kita 
bisa bayangkan bagaimana semrawutnya udara di atas Jakarta dan bagi kita yang kebetulan hanya punya radio dengan teknologi yang pas-pasan, siap-siap saja untuk menerima suara yang jauh dari jernih dan terkadang berdenging.

Dari kasus itu saja kita bisa bayangkan kalau tidak ada regulasi yang mengaturnya, siapa pun bisa mengudara hingga mengacaukan suara pemancar lain yang menggunakan frekuensi yang sama atau berdekatan. Padahal, spektrum frekuensi radio tidak hanya diperuntukkan bagi stasion radio semata tetapi juga untuk hal lain seperti transportasi, telepon seluler, dan lain sebagainya.

Kedua, spektrum frekuensi radio dimiliki oleh publik. Ini berarti pengusaha atau perusahaan media penyiaran sebenarnya meminjam frekuensi kepada publik yang direpresentasikan oleh negara dan karenanya tidak bisa diperjualbelikan dan diwariskan kepada anak cucunya. Hal yang terjadi sekarang adalah kepemilikan media penyiaran dengan gampang bisa dialihtangankan. Sebagai contoh, kelompok usaha Bimantara Citra dengan MNC-nya mengambil alih kepemilikan di RCTI, Global TV, dan TPI. Atau sebuah stasion radio di Bandung, yang karena pemiliknya bercerai, menjual radio-nya sebagai bagian dari harta gono-gini.

Dan alasan ketiga, media penyiaran haruslah bertanggung jawab kepada masyarakat selaku pemilik frekuensi radio dengan memberikan kerja dan tayangan terbaik. Sejatinya, media penyiaran berfungsi sebagai media komunikasi, informasi, dan tentunya media pendidikan selain juga sebagai media hiburan. Pada tataran ini tidak ada hal yang kontroversial dengan fungsi dari sebuah media penyiaran. Persoalan baru muncul manakala media bersentuhan dengan sisi bisnis. Karena di sini muncul, persepsi, perspektif, dan kepentingan yang berbeda-beda.

Dalam bisnis, meraih keuntungan yang sebesar-besarnya dengan biaya yang serendahrendahnya adalah sah. Jika dikaitkan dengan media penyiaran, tentunya ini terkait dengan biaya produksi yang minim tetapi memperoleh kue iklan yang besar. A tas nama bisnis, terjadilah eksploitasi berlebihan di mana perasaan publik terabaikan.
Dengan tingkat penetrasi yang hampir $90 \%$ untuk televisi dan 39\% untuk radio, bisa dibayangkan dampak yang timbul bagi khalayak media penyiaran ini. Tentu saja dampak bisa baik dan bisa juga buruk. Namun, jika dihadapi tidak dengan kekritisan, maka dampak buruk jauh lebih besar mungkin terjadi daripada sebaliknya. Dan sayangnya, masyarakat Indonesia dengan tingkat keterdidikan yang rendah, sangat rentan terpengaruh.

Sedikit uraian mengenai pengaruh televisi kepada anak-anak, remaja, dan kaum ibu di bawah ini bisa menggambarkan mengenai dampak televisi.

Anak-anak adalah korban pertama. Banyak kalangan menjadikan televisi sebagai baby sitter bagi anak-anak mereka. Tampaknya memang tidak bermasalah karena si anak cenderung untuk diam dan asyik memelototi sang gambar bergerak. Namun, berbagai penelitian dan berbagai fakta menyebutkan "meletakkan" anak-anak, apalagi usia dini, sangat berbahaya baik perkembangan fisik dan psikis. Anak usia di bawah dua tahun, seperti yang dijelaskan Rahmita P. Soendjono, seorang psikolog anak, yang dibiarkan oleh orang tuanya menonton akan menyerap pengaruh yang merugikan. Ini terutama, pada perkembangan otak, emosi, sosial, dan kemampuan kognitif anak.

Sementara, pada kasus remaja, lain lagi halnya. Remaja, meski jauh lebih baik dalam menangkap tayangan televisi dibanding anak-anak, namun mereka berada dalam fase psikologis yang labil. Mereka sedang dalam proses pencarian jati diri. Proses ini ditandai dengan melakukan identifikasi pada sesuatu yang dianggap hebat. Hal inilah yang kemudian dimanfaatkan oleh televisi. Proses identifikasi yang memenuhi seluruh gerak dan impuls remaja justru dimanfaatkan dan dijinakkan oleh media televisi untuk menciptakan ketergantungan. Hal yang terjadi selanjutnya adalah mereka dipaksa untuk tidak menjadi dirinya sendiri, melainkan menjadi menurut kehendak kepentingan.

Berbagai agenda kepentingan yang disodorkan oleh media adalah dalam kerangka menciptakan ketergantungan. Hal ini menjadikan 
para remaja kita tidak mempunyai pengalaman empirik untuk melakukan empati sosial dan pengaruh yang terbesar adalah akan terciptanya para remaja dengan kepribadian yang pasif, yang tidak punya kemauan untuk berekspresi, karena memang televisi telah memenuhi seluruh ruang kebutuhannya secara virtual. Berbagai tayangan sinetron, tanpa perlu menyebut judul, bisa kita dapati. Dengan tema remaja, mereka hanya mengeksploitasi kehidupan remaja dalam satu sisi untuk kemudian mereduksinya menjadi sebuah fantasi. Fantasi yang tercipta bukanlah dalam pengertian yang sebenarnya, tetapi lebih dalam kemudahan mendapatkan sesuatu, sebagaimana yang sering ditampilkan di layar kaca.

Hal yang sama pun terjadi pada kaum ibu. Bahkan, kelompok perempuan dewasa ini menjadi sasaran paling strategis bagi media. Lihat saja, misalnya, acara-acara pada jam ibu rumah tangga ada di rumah. Mulai dari talk show, infotainment, hingga sinetronnya dijejali dengan berbagai produk iklan yang ditujukan bagi kaum ibu. Dalam struktur rumah tangga di Indonesia, ibu adalah manager keuangan yang berfungsi menjalankan roda ekonomi keluarga. Maka bisa dibayangkan efek domino yang terjadi. Jika manajernya terbujuk maka mudahlah yang lainnya. Masyarakat konsumsi pun lalu bisa tercipta.

Jika menyimak pengaruh seperti tersebut di atas sudah seyogianya pengelola media penyiaran hendaknya mengerti dan paham betul mengapa mereka harus memberikan acara terbaik bagi masyarakatnya.

Jika pengelola dihadapkan pada persoalan bahwa mereka harus mengerti dan paham dalam memperlakukan khalayaknya, maka kita selaku khalayak pun dituntut untuk secara arif memperlakukan media. Lantas apa yang bisa dilakukan oleh publik? Jawabnya banyak. Jika berkaca pada UU No 32 Tahun 2002, mengenai Penyiaran, maka publik punya peran yang lebih besar. Pertama, publik berhak menentukan perijinan. Tentu tidak semua orang berhak mengeluarkan izin. Dalam kasus penyiaran, maka publik di sini direpresentasikan dalam sebuah lembaga yang dikenal sebagai regulator body yang di Indonesia kita kenal sebagai Komisi Penyiaran Indonesia (KPI). Kedua, publik berhak mengajukan keberatan terhadap isi siaran. Selama ini hampir tidak pernah ada kontrol terhadap isi siaran. Membiarkan media televisi Indonesia melenggang tanpa pengawasan, tanpa kontrol adalah sikap yang berbahaya sekaligus bodoh. Berbagai bentuk materi siaran, apalagi yang berjenis hiburan seperti sinetron, kuis, infotainment, atau reality show seringkali lepas dari norma-norma kepatutan sebuah karya kreatif, yang mestinya juga harus bertanggung jawab pada tumbuhnya eksplorasi masyarakatnya. Dr. Meuthia Hatta, Menteri Negara Pemberdayaan Wanita, pada 24 Juli yang lalu mengeluarkan pernyataan seperti yang dikutip oleh Tribun Jabar, "sinetron Indonesia tak berkualitas! Artisnya cantik-cantik, ganteng-ganteng, tapi jalan ceritanya amburadul." Munculnya berbagai kritik dan keluhan sebagian masyarakat atas kualitas tayangan program televisi Indonesia, seperti halnya pernyataan Meuthia Hatta, menunjukkan hal itu dengan jelas. Banyak kita jumpai sinetron yang bukan saja rendah kualitas teknik dan penyampaiannya, tetapi juga rendah dalam kualitas tematik, setting sosial, serta miskin pendalaman materi. Apalagi, rendahnya kreativitas produser itu bergabung dengan rendahnya sensibilitas pihak pengelola televisi. Kedua hal tersebut menjadi faktor yang paling berpengaruh terhadap rendahnya kreativitas pekerja kreatif. Untuk itulah maka diperlukan kontrol publik. Bentuk kontrol yang bisa dilakukan oleh publik bukan dengan berdemo lantas merusak gedung di mana media itu berada, seperti dulu yang pernah terjadi pada Jawa Pos, tetapi menyalurkan keberatannya melalui lembaga atau institusi yang ditunjuk dalam hal ini KPI. Ketiga, publik berhak menolak kehadiran sebuah lembaga penyiaran maupun isi siaran. Tentu penolakannya ini didasari oleh alasan logis yang masuk akal. Inilah yang kemudian terjadi dan menimpa kasus majalah Playboy Indonesia.

Amerika adalah sebuah negara yang seringkali dijadikan rujukan ketika kita berbicara tentang demokrasi, terlepas setuju atau tidak setuju. Namun, untuk negara se-liberal AS pun, regulasi masih 
diberlakukan. Ada beberapa alasan yang kemudian menunjukkan kepada kita bahwa ternyata regulasi penting dan harus diberlakukan. Alasan tersebut, antara lain:

Pertama, masalah ekonomi. AS adalah sebuah negara yang mendasarkan sistem perekonomiannya pada ekonomi pasar (kapitalis). Ekonomi pasar mempunyai dua asumsi, yaitu: kompetisi akan menghasilkan sesuatu yang baik bagi masyarakat dan praktek bisnis yang tidak adil tidak diizinkan karena akan mengurangi kadar kompetisi. Yang dimaksud dalam pernyataan tersebut adalah kompetisi pada gilirannya diharapkan menghasilkan suatu produk yang baik dan murah yang bisa dijangkau masyarakat. Secara teoretis, perusahaan yang menghasilkan produk yang baik dengan harga yang murahlah yang akan bertahan dalam persaingan. Meskipun begitu,

Tabel 1: Kepemilikan Silang Media Elektronik

\begin{tabular}{|c|c|c|c|}
\hline Nama kelompok usaha & Nama media & Jenis usaha & keterangan \\
\hline Bimantara Citra & $\begin{array}{l}\text { RCTI } \\
\text { Global tv } \\
\text { TPI } \\
\text { Trijaya FM Jakarta } \\
\text { Prapanca FM Medan } \\
\text { SCFM Surabaya } \\
\text { ARHFM Jakarta }\end{array}$ & $\begin{array}{l}\text { Televisi } \\
\text { Televisi } \\
\text { Televisi } \\
\text { Radio } \\
\text { Radio } \\
\text { Radio } \\
\text { Radio }\end{array}$ & \\
\hline Kompas gramedia group & $\begin{array}{ll}\text { TV } 7 & \\
\text { Sonora FM Jakarta } \\
\text { Salvatore } & \text { FM } \\
\text { Surabaya } & \\
\text { Bikima } & \text { FM } \\
\text { Yogyakarta } & \end{array}$ & $\begin{array}{l}\text { Televisi } \\
\text { Radio } \\
\text { Radio } \\
\text { Radio }\end{array}$ & 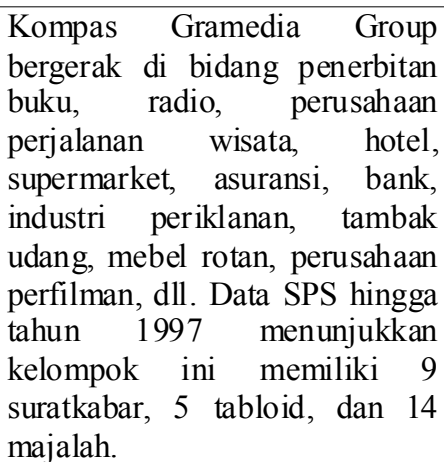 \\
\hline Indosiar Visual Mandiri & $\begin{array}{l}\text { Indosiar } \\
\text { Elshinta FM Jakarta }\end{array}$ & $\begin{array}{l}\text { Televisi } \\
\text { Radio }\end{array}$ & \\
\hline $\begin{array}{l}\text { Kelompok } \quad \text { Media } \\
\text { Indonesia }\end{array}$ & Metro TV & Televisi & $\begin{array}{l}\text { Menerbitkan Media Indonesia } \\
\text { dan Lampung Post }\end{array}$ \\
\hline Jawa Pos Group & $\begin{array}{l}\text { JTV Surabaya } \\
\text { RTV Pekan Baru } \\
\text { Batam TV } \\
\text { Dan 6 tv local } \\
\text { lainnya }\end{array}$ & $\begin{array}{l}\text { Televisi } \\
\text { Televisi } \\
\text { Televisi } \\
\text { Televisi }\end{array}$ & $\begin{array}{l}\text { Hingga tahun 1997, ekspansi } \\
\text { jawa pos group menghasilkan } \\
\text { kepemilikan } 20 \text { surat kabar, } 5 \\
\text { tabloid mingguan, dan } 4 \\
\text { majalah. Ini di luar } 11 \\
\text { percetakan, } 1 \text { pabrik kertas, dan } \\
9 \text { perusahaan non penerbitan yg } \\
\text { bergerak di wilayah perbankan, } \\
\text { hotel, internet service provider, } \\
\text { dan real estate. }\end{array}$ \\
\hline
\end{tabular}

Sumber : Sudibyo, 2004:44 
praktek bisnis yang tidak adil seperti monopoli, dilarang. Monopoli bisa terjadi jika perusahaan pesaing tidak ada dan lemah daya saingnya, sementara produsenlah yang menentukan harga di pasar. Ini tidak sesuai dengan ekonomi pasar yang berdasar pada hukum permintaan dan penawaran. Untuk itulah kemudian pemerintah USA membuat Telecommunication Act untuk melindungi usaha telekomunikasi dari praktekpraktek monopoli.

Hal serupa juga berlaku di Indonesia yang membuat UU telekomunikasi No 36 Tahun 1999 dan Undang-undang No 5 Tahun 1999, mengenai praktek monopoli, meskipun pemerintah RI tidak sepenuhnya mendasarkan sistem ekonominya pada ekonomi pasar. Khusus mengenai lembaga penyiaran, seperti yang tercantum dalam UU penyiaran No 32 Tahun 2002, secara tegas dinyatakan dalam Pasal 5, Ayat g, mengenai larangan monopoli kepemilikan dan dukungan terhadap persaingan yang sehat di bidang penyiaran. Meskipun ternyata dalam prakteknya masih kita dapati usaha-usaha para pemilik modal untuk melakukan konglomerasi media, seperti pada tabel 1 .

Kedua, regulasi diperuntukkan bagi usahausaha yang memang secara notabene menghasilkan dampak negatif yang luas di masyarakat. Contoh yang pas untuk ini adalah peraturan mengenai tembakau atau rokok. Tembakau nyata-nyata, berdasarkan riset, mempunyai dampak buruk bagi kesehatan, tetapi masih juga diperdagangkan. Untuk itu maka pemerintah perlu membuat regulasi agar masyarakat lain yang memang tidak suka dengan tembakau bisa terjaga haknya untuk hidup secara sehat. Hal serupa juga menimpa Indonesia. Adalah suatu dilema tersendiri ketika akan melarang produk rokok dengan alasan karena cukai yang dihasilkan bagi pemasukan anggaran negara mencapai triliunan rupiah pertahunnya. Sementara pemerintah pun sadar bahwa merokok adalah sesuatu yang tidak baik bagi kesehatan.

Ketiga, regulasi dibuat jika produk atau perusahaan menghasilkan dampak negatif bagi individu yang lebih besar daripada manfaatnya secara keseluruhan bagi masyarakat. Hak atas informasi tercantum dalam First Amandment. Orang berhak atas informasi yang ada di sekitarnya dan media bertugas untuk menyampaikannya sesuai dengan fungsinya sebagai pengawas lingkungan. Namun, dalam usahanya menyampaikan informasi, cara bagaimana media mendapatkan informasi tersebut haruslah sesuai dengan peraturan yang ada. Para jurnalis hendaknya mengikuti kaidah serta etika jurnalistik yang berlaku, seperti menghindari penggunaan kamera tersembunyi dan mikrofon secara tidak sah dalam mengejar informasi dari narasumber. Privasi narasumber tetaplah harus dijaga. Atau juga menghindari adanya 'penjulukan' yang tidak etis atas diri seseorang oleh media. Untuk kasus Indonesia, hal ini diakomodasi dalam UU Pers No 40 Tahun 1999, dan UU Penyiaran No 32 Tahun 2002, di mana salah satu pasalnya mengatur tentang hak privasi dari narasumber.

Keempat, bagi pemberlakuan regulasi oleh pemerintah AS adalah peraturan mengenai arus informasi selama terjadinya perang. Ketika terjadi peperangan, maka pemerintah berhak untuk melakukan upaya sensor dan membatasi ruang gerak media jika dirasa itu membahayakan para tentara AS yang terlibat dalam peperangan. Adalah wajar jika selama perang, media lebih didominasi oleh pemberitaan yang sifatnya propaganda. Ini dimaksudkan agar moral para tentara tetap terjaga dan masyarakat mau mendukung pemerintah memenangkan perang tersebut. Jika hal yang sebenarnya terjadi dalam sebuah peperangan dijelaskan oleh media secara gamblang, tentunya tidak akan pernah ada pihak-pihak yang mau berperang. Untuk itulah mengapa selama terjadinya Perang Vietnam dan perang Irak para jurnalis yang ikut berperang dibatasi ruang geraknya.

Kelima, yang membuat pemerintah AS untuk memberlakukan regulasi adalah alasan keamanan dalam negerinya. Media dibatasi untuk meliput dan mengungkap sebuah kasus jika itu dirasa mengancam stabilitas dan keamanan dalam negeri AS. 


\section{Kesimpulan}

Bagaimana seharusnya kita mengkritisi, menilai, dan memaklumi televisi Indonesia adalah menjadi tugas kita bersama. Pemaparan berbagai persoalan di atas hendaknya menyadarkan kita bahwa sesungguhnya produk tayangan yang muncul lebih didasari oleh selera mereka yang membuat dan menayangkannya, bukan karena selera masyarakat atau permintaan pasar seperti yang selama ini kita kenal.

Sudah sepantasnya masyarakat mengetahui latar belakang permasalahannya. Dengan demikian, masyarakat mampu menempatkan posisi untuk menuntut hak-haknya secara memadai. Memang menonton televisi adalah gratis, namun tidak berarti stasiun televisi boleh melakukan kesewenang-wenangan. Karena ada harga yang harus dibayar oleh masyarakat penontonnya, yaitu karakter, kepribadian, dan kemandirian.

Kita mungkin bisa berharap, dengan adanya regulasi yang jelas dan diberlakukan secara tegas, peranan ideal media sebagai sarana pembelajaran dan pendidikan agar masyarakat kian memiliki sikap kritis dan mampu berpikir serta bertindak mandiri dapat dicapai. Semoga.

\section{Daftar Pustaka}

\section{A. Buku}

Budiman, Kris. 2002. Di Depan Kotak Ajaib: Menonton Televisi sebagai Praktik Konsumsi. Galang Press. Yogyakarta.

Gazali, Effendi, et al. 2003. Konstruksi Sosial Industri Penyiaran. Penerbit Departemen Ilmu Komunikasi FISIP UI. Jakarta.

Hanim, Masayu S, et al. 2006. Dampak Tayangan Pornografi, Kekerasan dan Mistik di Televisi: di Palembang dan Semarang. LIPI. Jakarta.

Sudibyo, Agus. 2004. Ekonomi Politik Media Penyiaran. LKIS. Yogyakarta.

Razak, Abdul dan Gunawan Subagio. 2000. "Debat Besar Pornografi. " Penerbit HU Pikiran Rakyat Bandung. Bandung.

Wirodono, Sunardian. 2006. Matikan TV-Mu ! Resist Book. Yogyakarta.

\section{B. Sumber Lain}

Undang - undang Penyiaran No 32 Tahun 2002

Harian Umum Tribun Jabar, 24 Juli 2007. 
